6. Поступове зникнення сосни в Україні [Електронний ресурс] Режим доступу: https://cutt.ly/2hrV60r

7. Державне агентство лісових ресурсів України [Електронний pecypc] - Режим доступу: https://cutt.ly/0hrBxCN

8. Небезпечний короїд продовжує знищувати ліси [Електронний pecypc] - Режим доступу: https://cutt.ly/2hrBT8R

DOI https://doi.org/10.30525/978-9934-26-006-3-20

\title{
МОРФОМЕТРИЧНІ ПАРАМЕТРИ HERACLEUM SOSNOWSKYI MANDEN В УМОВАХ УРБОЕКОСИСТЕМИ ІВАНО-ФРАНКІВСЬКА
}

\author{
Різничук Н. I. \\ кандидат біологічних наук, дочент, \\ дочент кафедри біології та екології \\ ДВНЗ «Прикарпатський національний університет \\ імені Василя Стефаника» \\ Бабак О. В. \\ аспірант кафедри біології та екології \\ ДВНЗ «Прикарпатський національний університет \\ імені Василя Стефаника» \\ Васечко Л. І. \\ методист факультету природничих наук \\ ДВНЗ «Прикарпатський національний університет \\ імені Василя Стефаника» \\ м. Івано-Франківськ, Україна
}

Загальною морфологічною ознакою Heracleum sosnowskyi Manden в умовах урбанізованого середовища $є$ зменшення площі вегетуючої поверхні, що можна розглядати як адаптивну ознаку, направлену на зменшення площі контакту з забрудненим аерогенним середовищем. Інтенсивність прояву вказаної тенденції визначається рівнем антропогенного пресингу на конкретні біотопи урбоекосистеми ІваноФранківська. Вказаний ефект також може бути спричинений механічним ушкодженням рослини внаслідок систематичного 
витоптування, або зміною стратегії виживання популяції за дії стресових чинників [1, с. 714].

Вступ. Хронічний вплив полютантів різної інтенсивності викликає морфометричні зміни вегетативних та генеративних органів рослин. Найбільш чутливими серед них можна вважати ті, що тісно корелюють із величиною первинної продукції та характеризують газообмін у системі «рослина - середовище». Ці параметри можна також розглядати як біоіндикаційні ознаки екологічного стану довкілля [2, c. 196].

Матеріали й методи. Для дослідження реакцій рослин на стресові фактори урбанізованого середовища та наступної оцінки на їх основі стану міського довкілля було використано комплекс морфометричних та онтогенетичних методів [3, с. 48; 4, с. 54]. Дослідження замірювання проводили за загальноприйнятими методиками.

Результати досліджень. Одержані результати вказують на зміну розмірів листкових пластинок (тобто кількість, ширина та довжина листкових пластино) популяцій Heracleum sosnowskyi Manden у примагістральних та селітебних біотопах в послідовностях у порівнянні 3 фоновою територією: Центральний $\rightarrow$ Південний $\rightarrow$ Південнозахідний $\rightarrow$ Північно-східний $\rightarrow$ Північний (рис. 1. А-В; 2. А-В).

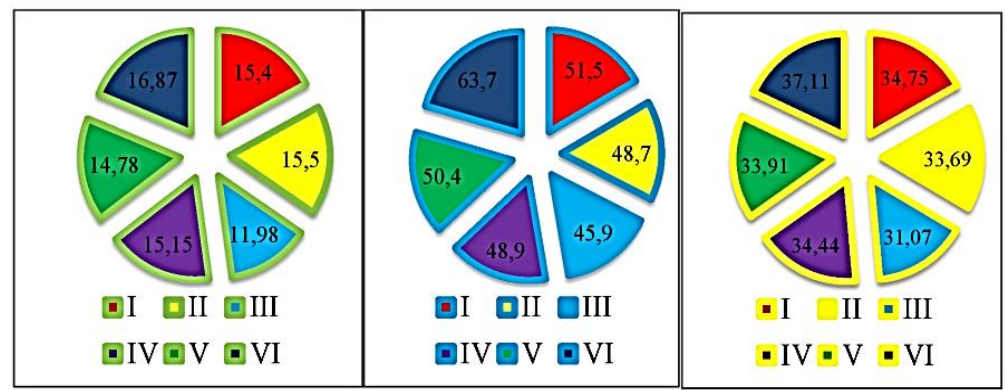

A

Б

$\mathrm{B}$

Рис. 1. Особливості листкової системи Heracleum sosnowskyi Manden у примагістральних біотопах урбоекосистеми Івано-Франківська

(тут і надалі): А - Кількість листків; Б - Довжина листків;

В - Ширина листків.; I - Північний район; II - Північно-східний район; III - Центральний район; IV - Південний район;

V - Південно-західний район; VI - Фонова територія 


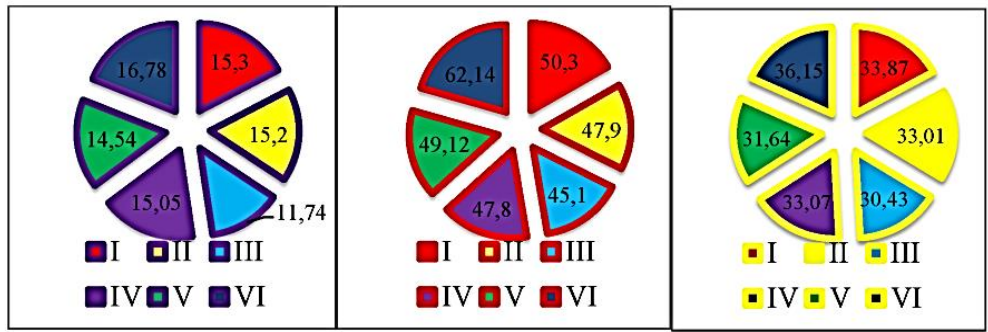

A

Б

B

Рис. 2. Особливості листкової системи Heracleum sosnowskyi Manden у селітебних біотопах урбоекосистеми Івано-Франківська

Особинам популяції Heracleum sosnowskyi Manden фонової території примагістрального та селітебного біотопу характерні наступні значення аналізованих морфометричних показників: загальна кількість листків - 16,87 та 16,78, довжина листків - 63,47 та 62,14, ширина листків - 37,11 та 36,15.

Максимальні відхилення аналізованих показників від фонових значень встановлені для особин центрального району примагістрального та селітебниого біотопу урбоекосистеми ІваноФранківська. Так, загальна кількість листків Heracleum sosnowskyi Manden тут коливається у діапазоні 11,98 та 11,74 , довжина листків 45,9 та 45,1, а ширина листків - 31,07 - 30,43. Найвищі показники віталітету у межах міста властиві для популяцій північного району примагістрального та селітебного біотопу урбоекосистеми ІваноФранківська досліджувані морфометричні параметри тут складають відповідно: загальна кількість листків 15,4 та 15,3 , довжина листків 51,5 та 50,3, а ширина листків 34,75 та 33,87 .

Найбільш стабільною ознакою Heracleum sosnowskyi Manden в умовах урбогенного навантаження різної інтенсивності $\epsilon$ загальна довжина підземної та надземної частини, а також загальна довжина. У біотопах урбоекосистеми Івано-Франківська загальна довжина підземної частини флуктує у діапазоні 44,1 - 47,3 для примагістральних біотопів, а селітебних від 44,8 до 48,1. Так, загальна довжина надземної частини для примагістрального біотопа урбоекосистеми Івано-Франківська характеризується такими показниками, як 159,9 - 177,8, а для селітебних біотопів 151,2 - 172,2. Така закономірність прояву ознаки може бути зумовлена мікрокліматичними та мікроедафічними особливостями вказаних біотопів урбоекосистеми Івано-Франківська (табл. 1). 
International scientific and practical conference

Порівняльна характеристика підземної та надземної фітомаси Heracleum sosnowskyi Manden у примагістральних та селітебних біотопах урбоекосистеми Івано-Франківська

\begin{tabular}{|c|c|c|c|c|}
\hline \multirow{2}{*}{$\begin{array}{c}\text { Назва } \\
\text { території }\end{array}$} & \multicolumn{2}{|c|}{$\begin{array}{c}\text { Довжина підземної } \\
\text { частини }\end{array}$} & \multicolumn{2}{|c|}{$\begin{array}{c}\text { Довжина надземної } \\
\text { частини }\end{array}$} \\
\cline { 2 - 5 } & $\begin{array}{c}\text { Примагіст } \\
\text { ральний } \\
\text { біотоп }\end{array}$ & $\begin{array}{c}\text { Селітебний } \\
\text { біотоп }\end{array}$ & $\begin{array}{c}\text { Примагістра } \\
\text { льний } \\
\text { біотоп }\end{array}$ & $\begin{array}{c}\text { Селітебний } \\
\text { біотоп }\end{array}$ \\
\hline Північний р-н & 47,3 & 48,1 & 177,8 & 172,2 \\
\hline $\begin{array}{c}\text { Північно- } \\
\text { східний р-н }\end{array}$ & 44,8 & 45,2 & 169,2 & 170,3 \\
\hline $\begin{array}{c}\text { Центральний } \\
\text { р-н }\end{array}$ & 44,1 & 44,8 & 141,5 & 151,2 \\
\hline Південний р-н & 46,7 & 46,9 & 173,7 & 172,2 \\
\hline $\begin{array}{c}\text { Південно- } \\
\text { західний р-н }\end{array}$ & 45,9 & 46,3 & 159,9 & 164,2 \\
\hline $\begin{array}{c}\text { Фонова } \\
\text { територія }\end{array}$ & 51,2 & 51,5 & 195,6 & 192,4 \\
\hline
\end{tabular}

Загальна довжина надземної частини для популяції Heracleum sosnowskyi Manden у примагістральному біотопі склала від 225,5 185,6 , а для селітебного біотопа показник склав 220,3 - 196. Досить помітно вирізняється фонова територія показники якої склали для примагістрального біотопу 195,6, а для селітебного біотопу 243,9.

Одержані результати вказують на зміну загальних розмірів популяцій Heracleum sosnowskyi Manden у примагістральних та селітебних біотопах урбоекосистеми Івано-Франківська в послідовностях у порівнянні з фоновою територією: Центральний $\rightarrow$ Південний $\rightarrow$ Південно-західний $\rightarrow$ Північно-східний $\rightarrow$ Північний.

У межах урбоекосистеми середня кількість квітконосів популяцій Heracleum sosnowskyi Manden у примагістральних та селітебних біотопах урбоекосистеми Івано-Франківська коливається від 9-6, та 3 - 8 при 12 на фоновій території, а діаметр їх суцвіть коливається в межах - 37 - 41 та 35 - 43 при 47 - 49 на фоновій території (рис. 5.7; 5.8).

Висновки. Отже, зменшення аналізованих показників відбувається у послідовному ряді досліджених примагістральних та селітебних біотопах урбоекосистеми Івано-Франківська в послідовностях у порівнянні 3 фоновою територією: Центральний $\rightarrow$ Південний $\rightarrow$ Південно-західний $\rightarrow$ Північно-східний $\rightarrow$ Північний. Морфометричні параметри генеративних і вегетативних органів Heracleum sosnowskyi Manden чутливо реагують на інтенсифікацію урботехногенного 
пресингу у примагістральних та селітебних біотопах, що свідчить про значну лабільність виду у змінних умовах середовища та про його вику біоіндикаційну цінність. Максимально інформативними біоіндикаційними параметрами $є$ площа листкової пластинки, загальна довжина рослини та середня кількість квітконосів і їх діаметр у перерахунку на одну особину популяції.

\title{
Література:
}

1. Коваленко I.M. Структура популяцій домінантів трав'яночагарничкового ярусу в лісових фітоценозах Деснянсько-Старогутського національного природного парку. Онтогенетична структура. Український ботанічний журнал. 2005. Т. 62, № 5. С. 707-714.

2. Вихор Б.І. Проць Б.Г. Борщівник Сосновського (Heracleum sosnowskyi Manden.) на Закарпатті: екологія, поширення та вплив на довкілля. Біологічні студії, 2012. С. 185-196.

3. Протопопова В.В. Небезпечні бур'яни. Біологічні забруднювачі довкілля м. Києва / В.В. Протопопова. М.В. Шевера. Київ : ТОВ «Поліграф-Експрес», 2010. 48 с.

4. Різничук Н.I. Онтогенез Polygonatum multiflorum L. на Прилуквинській височині. Біологічний вісник: матеріали XVI міжнародної наукової конференції «Роль ботанических садов в изучении онтогенеза интродуцированных растений». 2008. Т. 12, № 2. С. 54-56.

DOI https://doi.org/10.30525/978-9934-26-006-3-21

\section{СЕЗОННИЙ РОЗВИТОК САДОВИХ ТРОЯНД ЗА КЛІМАТИЧНИХ ЗМІН В УМОВАХ СТЕПУ УКРАЇНИ}

\author{
Чипиляк Т. Ф. \\ кандидат біологічних наук,
} завідувачка відділу природної та культурної флори

Криворізький ботанічний сад Національної академії наук України м. Кривий Ріг, Дніпропетровська область, Украӥна

Зміна клімату відноситься до екологічних ризиків, які визначають екологічну безпеку навколишнього середовища і проявляються у зміні температури, атмосферних опадів, гідрологічного режиму та відхилення їх параметрів від кліматичної норми певної географічної 